\title{
Science
}

March 2012, Vol. 335 (6073), Pages 1219-1222

http://dx.doi.org/10.1126/science. 1215400

(C) 2012 American Association for the Advancement of

Science. All Rights Reserved.

\section{Intensifying Weathering and Land Use in Iron Age Central Africa}

\author{
Germain Bayon*, Bernard Dennielou, Joël Etoubleau, Emmanuel Ponzevera, Samuel Toucanne, \\ Sylvain Bermell
}

IFREMER, Unité de Recherche Géosciences Marines, F-29280 Plouzané, France

*: Corresponding author: Germain Bayon, Tel.: + 33298224630 ; fax: + 33298224570 ;

email address : gbayon@ifremer.fr

\begin{abstract}
:
About 3000 years ago, a major vegetation change occurred in Central Africa, when rainforest trees were abruptly replaced by savannas. The consensus is that the forest disturbance was caused by climate change. We show here that chemical weathering in Central Africa, reconstructed from geochemical analyses of a marine sediment core, intensified abruptly at the same period, departing significantly from the long-term weathering fluctuations related to the Late Quaternary climate. Evidence that this weathering event was also contemporaneous with the migration of Bantu-speaking farmers across Central Africa suggests that human land-use intensification at that time already had a significant impact on the rainforest.
\end{abstract}

A major vegetation change occurred in Central Africa during the third millennium before present, when mature evergreen trees were abruptly replaced by savannas and secondary grasslands (1-4). The consensus is that the forest disturbance was caused by a regional climate change (1-4). However, this episode of forest clearance occurred contemporaneously with the migration of Bantu-speaking peoples from near the modern Nigeria-Cameroon border (5-9). The so-called Bantu expansion led to diffusion of 
agriculture and iron smelting technology across Central Africa, with potential impacts on the environment (10). Whether the Bantu farmers played an active role in the Central African deforestation event remains an open question.

To provide further constraints on this issue, we have reconstructed the late Quaternary history of chemical weathering in Central Africa using a marine sediment record recovered off the mouth of the Congo River (Fig. 1). This core (KZAI-01; 0542' S, 11 $14^{\prime}$ E), collected at a water depth of $914 \mathrm{~m}$, provides a continuous record of the Congo River sediment discharge for about the last 40,000 years (see supporting online material, SOM). Although changes in chemical weathering intensity on continents are driven primarily by natural factors, such as physical weathering rates, vegetation, rainfall and temperature (11, 12), intensive land-use and accelerated soil denudation, by increasing the surface area of minerals and rocks exposed to weathering, can also dramatically lead to much higher rates of chemical alteration (13). The degree of chemical weathering of fine-grained sediments can be inferred from the ratio of aluminium to potassium $(\mathrm{Al} / \mathrm{K})$. Potassium is highly mobile during chemical weathering and typically depleted in soils, whereas aluminium is one of the most immobile elements, being incorporated into secondary clay minerals such as kaolinite (see SOM Text). High $\mathrm{Al} / \mathrm{K}$ ratios in Congo fan sediments are therefore considered to be indicative of periods of intense chemical weathering in the Congo Basin (14). Because downcore variations of the bulk chemical composition can also reflect changes in sediment source, we measured neodymium (Nd) and hafnium (Hf) isotopic ratios to discriminate between both weathering and provenance signals in our sediment record. The Nd isotopic signature of terrigenous sediments is retained during continental weathering and subsequent transport, thereby providing direct information on the geographical provenance of sediment (15). Hafnium isotopes exhibit globally similar 
behavior, but are also prone to significant fractionation during chemical weathering, because incongruent dissolution of silicate rocks leads to products of erosion having very distinctive but systematic Hf isotopic signatures (16, 17; see SOM Text).

In this study, the bulk sedimentary major element composition of KZAI-01 was determined quantitatively at a 5-cm sampling interval (Fig. 2), corresponding to a temporal resolution of about 100-400 years. The age model for KZAI-01 is based on accelerator mass spectrometry (AMS) radiocarbon measurements of mixed marine carbonate fractions and tuning to a well-dated nearby sediment record from the Gulf of Guinea (GeoB6518-1; see location in Fig. 1). Additional age constraints were also obtained from ${ }^{14} \mathrm{C}$-AMS dating of bulk sediment organic carbon (Fig. 2). Figure 3A shows that the $\mathrm{Nd}$ isotopic composition of sediments deposited at site KZAI-01 (average $\varepsilon_{\mathrm{Nd}} \sim-15.9 \pm 0.6$ ) is almost constant and very similar to that reported for present-day riverine particulates from the Congo Basin (18). This indicates that the source of material delivered to the ocean by the Congo River has remained unchanged during the Late Quaternary. By contrast, Hf isotopes display significant downcore variations (from $\varepsilon_{\mathrm{Hf}} \sim-6.8$ to -13.9 ), which correlate well with the $\mathrm{Al} / \mathrm{K}$ depth-profile (Fig. 3A,B). Because grain-size is homogeneous in this core, with medians ranging from 4 to $6 \mu \mathrm{m}(17)$, the large range of $\varepsilon_{\mathrm{Hf}}$ values cannot be explained by changes in the relative proportions of mineral phases having distinct Hf isotope signatures. Importantly, therefore, these data show that downcore fluctuations of $\varepsilon_{\mathrm{Hf}}$ and $\mathrm{Al} / \mathrm{K}$ ratios at site KZAI-01 both reflect variations in chemical weathering intensity within the Congo River drainage basin, rather than changes in sediment provenance and/or grain-size. 
72 GeoB6518-1 suggests that much of the weathering signal at site KZAI-01 is driven by continental precipitation. From about 20,000 to 3,500 years ago, our weathering record exhibits strong correlation with the precipitation signal from core GeoB6518-1, inferred from the deuterium composition of plant waxes $(19,20)$ (Fig. 3C). This observation suggests that chemical alteration in the Congo Basin has responded quickly to regional climatic changes, at least for the time scales being considered here. The trends towards wetter conditions that are visible in the GeoB6518-1 deuterium record, between about 18 to 13 kyr BP and 12 to 9 kyr BP, coincide well with marked periods of intensifying chemical weathering. Similarly, the progressive onset of dryer conditions since ca. 6 kyr BP, which marks the end of the African Humid period, is accompanied by lower weathering rates. Reduced weathering rates also occurred during the Younger Dryas, between approximately 12.8 and 11.5 kyr BP, a period characterized by lower precipitation levels in Central Africa (19). In comparison, the evolution of mean annual temperatures in Central Africa has been very gradual since the last deglaciation, rising smoothly from about $21^{\circ}$ to $25^{\circ} \mathrm{C}(21)$. Most probably, this suggests that temperature only played a minor role in controlling past chemical weathering variations in the Congo Basin during the Late Quaternary.

From about 3,500 years BP, an abrupt trend towards higher $\mathrm{Al} / \mathrm{K}$ and $\mathrm{Hf}$ isotope values indicates rapidly intensifying chemical weathering. The weathering peak, centered at around 2,500 years $\mathrm{BP}$, is characterized by the highest $\mathrm{Al} / \mathrm{K}$ and $\varepsilon_{\mathrm{Hf}}$ values measured throughout core KZAI-01, indicating that global weathering rates in the Congo Basin during that period were higher than at any other time in the last 40 thousand years. After 
94 about 2,000 year BP, chemical weathering intensity values decreased slightly, but still 95 remained at much higher levels than prior to 3,000 year BP. The weathering episode occurred contemporaneously with the major vegetation change that occurred in Central Africa during the third millenium BP, illustrated in Fig. 3E by the sudden increase in the abundance of herbaceous pollen taxa (Graminaea) at Lake Barombi Mbo (3) (see location in Fig. 1). This event is well-documented in numerous palynological and sedimentological records (1-4), from the Equatorial Atlantic coastal region to the eastern border of the Congo Basin, near Lake Tanganyika (Fig. 1). At many sites, proxy records for past vegetation patterns indicate a significant loss of primary forest between $~ 3,000$ and 2,200 calendar year BP, and its replacement by savannas and other pioneer formations. To some extent, this large scale deforestation event shaped the African rain forest into its present-day vegetation patterns $(1,2)$. The cause usually invoked for the forest disturbance is a global 106 shift towards seasonally dryer conditions in Central Africa $(1,4)$. This hypothesis is in agreement with the Late Holocene rainfall signals for tropical regions, which indicate reduced precipitation levels from $~ 4,000$ years BP $(1,19)$. At that time, one would expect the weathering signal at site KZAI-01 to follow the same way it evolved during the last 40 thousand years when continental climate became dryer, i.e. towards lower intensity levels

111 (lower $\mathrm{Al} / \mathrm{K}$ ratios). Instead, evidence that chemical alteration strongly intensified during the third millennium BP, departing therefore from the long-term weathering fluctuations related to the Late Quaternary climate, suggests that this weathering event was not triggered 114 by natural climatic factors.

We are confident that this pulse of intense chemical weathering does not reflect 117 reworking of sediments on the shelf, due to sea-level rise for example, or denudation of 
strongly weathered ancient soils from the Congo Basin. Indeed, at the time of deposition,

119 the global mean sea level in the oceans had already been close to modern values for several 120 millenia at least (22). In addition, the calibrated ages for bulk organic matter samples in

121 this part of core KZAI-1, which include a significant continental organic fraction (23), 122 agree well with those inferred from our age model (determined from radiocarbon dating of 123 marine carbonate material; see Table S3). Importantly, this suggests that the suspended 124 particles transported by the Congo River during that period were mainly derived from 125 relatively young soils, rather than from older tropical soils. Taken together, these 126 observations clearly show that the anomalously high $\mathrm{Al} / \mathrm{K}$ values in the upper part of core 127 KZAI-01 correspond to a true contemporaneous signal of chemical weathering from the 128 Congo Basin.

In fact, recent archaeological surveys showed that the deforestation event in the third 131 millennium BP coincided with the large-scale settlement of Bantu-speaking farmers in sub132 Equatorial Africa $(4,10,24)$. The first Bantu speakers were cultivators in the eastern 133 Nigeria and western Cameroon area, who began to spread eastward and southward about 134 4,000 years ago (5-9). From the third millennium BP, a major expansion wave was 135 associated with the introduction of agriculture into the central African rainforest $(5,10,24)$. 136 This period coincides with marked increases in the abundance of oil palm pollen at 137 numerous sites across west and central Africa, interpreted as evidence for intensifying plant 138 cultivation (25). In this region, numerous archeological sites containing ceramics, 139 domesticated crop remains, oil palm nuts, stone tools were dated between about 3,000 and 1402,000 years ago $(24,26-29)$. At that time, the cultivation of savanna crops, such as pearl 141 millet and yams, was made possible by the onset of seasonality alternance between wet and 
142 dry seasons $(4,24)$. The discoveries of several iron-working furnaces and smelted iron

143 artefacts in Cameroon, Gabon, Central African Republic and Congo, dating from the same

144 period or even older, also indicated that the Bantu farmers were carrying the technology for

145 iron metallurgy (29-33).

146

147 One hypothesis to link the rainforest crisis to intensifying human activities in Central 148 Africa during the third millennium BP has been to propose that the deforestation event 149 created favorable conditions for the settlement of Bantu farmers across Central Africa, 150 through opening of savanna corridors $(4,34)$. Alternatively, the introduction of novel 151 agricultural practices and iron smelting technology could also have led to intensive land 152 clearance for shifting cultivation and charcoal production, thereby being partly responsible 153 for the major vegetation change about 2,500 years ago (10). Because all of land-use, 154 anthropogenic deforestation, and agriculture would have significantly increased rates of soil 155 erosion and, as a consequence,_chemical weathering, intensifying human activities in sub156 Equatorial Africa hence represent a plausible explanation for the third millennium BP 157 weathering episode. Based upon our results, it is difficult to assess the degree to which 158 human land-use and/or climate change played a role during this Late Holocene 159 deforestation event. However, evidence from our proxy record that chemical weathering 160 rates at that time were unprecedented during the last 40 thousand years clearly suggest that 161 the environmental impact of human population in the central African rainforest was already 162 significant about 2,500 years ago, at least greater than that induced by the Late Quaternary 163 climatic oscillations. 


\section{References and Notes}

165 1. A. Vincens et al., J. Biogeog. 26, 879 (1999).

$166 \quad$ 2. J. A. Maley, IDS Bull. 33, 13 (2002).

167 3. J. Maley, P. Brenac, Rev. Palaeobot. Palynol. 99, 157 (1998).

168 4. A. Ngomanda, K. Neumann, A. Schweizer, J. Maley, Quat. Res. 71, 307 (2009).

169 5. J. Diamond, P. Bellwood, Science 300, 597 (2003).

$170 \quad$ 6. T. N. Huffman, A. Rev. Anthropol. 11, 133 (1982).

171 7. D. W. Phillipson, African Archaeology (Cambridge Univ. Press, Cambridge, 1993).

172 8. J. Vasina, J. Afr. Hist. 25, 129 (1984).

173 9. C. J. Holden, Proc. R. Soc. Lond. B 269, 793 (2002).

174 10. K. J. Willis, L. Gillson, T. M. Brncic, Science 304, 402 (2004).

175 11. A. F. White, A. E. Blum, Geochim. Cosmochim. Acta 59, 1729 (1999).

176 12. J. Gaillardet, B. Dupré, P. Louvat, C. J. Allègre, Chem. Geol. 159, 3 (1999).

177 13. P. A. Raymond, J. J. Cole, Science 301, 88 (2003).

178 14. R. R. Schneider, B. Price, P. J. Müller, D. Kroon, I. Alexander, Paleoceanography 12, 463 $179 \quad$ (1997).

180 15. S. L. Goldstein, R. K. O'Nions, P. J. Hamilton, Earth Planet. Sci. Lett. 70, 221 (1984).

181 16. G. Bayon et al., Geology 34, 433 (2006).

182 17. G. Bayon et al., Earth Planet. Sci. Lett. 277, 318 (2009).

183 18. C. J. Allègre, B. Dupré, P. Négrel, J. Gaillardet, Chem. Geol. 131, 93 (1996).

184 19. E. Schefuß, S. Schouten, R. R. Schneider, Nature 437, 1003 (2005). 
20. Hydrogen isotope abundances ( $\delta \mathrm{D}$, in \%o relative to VSMOW) in terrestrial plant waxes are controlled by the precipitation-evaporation balance and humidity levels in tropical areas, therefore reflecting predominantly continental rainfall fluctuations (19).

21. J. W. H. Weijers, E. Schefuß, S. Schouten, J. S. Sinninghe Damsté, Science 315, 1701 (2007).

22. K. Fleming, P. Johnston, D. Zwartz, Y. Yokoyama, K. Lambeck, J. Chappell, Earth Planet. Sci. Lett. 163, 327 (1998).

23. J. W. H. Weijers, S. Schouten, E. Schefuß, R. R. Schneider, J. S. Sinninghe Damsté, Geochim. Cosmochim. Acta 73, 119 (2009).

24. K. Neumann et al., Quat. Int., in press, doi:10.1016/j.quaint.2011.03.024.

25. M. A. Sowunmi, Veg. Hist. Archaeobot. 8, 199 (1999)

26. B. Clist, Archaeology in Gabon, 1886-1988. Afr. Archaeol. Rev. 7, 59 (1989).

27. J. Denbow, Afr. Archaeol. Rev. 8, 139 (1990).

28. C. M. Mbida, W. Van Neer, H. Doutrelepont, L. Vrydaghs, J. Archaeol. Sci. 27, 151 (2000).

29. A. A. Ndong, L'Anthropologie 106, 135 (2002).

30. M. K. H. Eggert, in The archaeology of Africa; food, metals and towns, T. Shaw, P. Sinclair, B. Andah, A. Okpoko, Eds. (Routledge, London, 1993), pp. 289-329.

31. R. Oslisly, in The growth of farming communities in Africa from the equator southwards, J. E.G. Sutton, Ed. (Azania, Nairobi, vols 29-30), pp 324-331.

32. E. Zangato, A. F. C. Holl, J. Afr. Archaeol. 8, 7 (2010).

33. D. Schwartz, H. de Foresta, R. Deschamps, R. Lanfranchi, C.R. Acad. Sci. Paris 310, 1293 (1990). 
34. D. Schwartz, Bull. Soc. Géol. Fr. 163, 353 (1992).

35. N. Babonneau, B. Savoye, M. Cremer, B. Klein, Mar. Petrol. Geol. 19, 445 (2002).

36. B. Savoye, N. Babonneau, B. Dennielou, M. Bez, Deep Sea Res. II 56, 2169 (2009).

37. M. Stuiver, P. J. Reimer, R. W. Reimer, CALIB 6.0 [http://calib.qub.ac.uk/calib/] (2010).

38. M. El Maghraoui, J. L. Joron, J. Etoubleau, P. Cambon, M. Treuil, Geostand. Newslett. 23, 59 (1999).

39. G. Bayon et al., Geostand. Geoanal. Res. 33, 51 (2009).

40. G. Bayon et al., Chem. Geol. 187, 179 (2002).

41. C. Pin, J. F. S. Zalduegui, Anal. Chim. Acta 339, 79 (1997).

42. N. C. Chu et al., J. Anal. At. Spectrom. 17, 1567 (2002).

43. S. B. Jacobsen, G. J. Wasserburg, Earth Planet. Sci. Lett. 50, 139 (1980).

44. J. Blichert-Toft, F. Albarède, Earth Planet. Sci. Lett. 148, 243 (1997).

45. T. Tanaka et al., Chem. Geol. 168, 279 (2000).

46. See data compilation for rock samples at earthref.org/databases/

47. J. M. Martin, M. Meybeck, Mar. Chem. 7, 173 (1979).

48. J. D. Vervoort, P. J. Patchett, J. Blichert-Toft, F. Albarede, Earth Planet. Sci. Lett. 168, 79 (1999).

49. J. D. Vervoort, T. Plank, J. Prytulac, Geochim. Cosmochim. Acta 75, 5903 (2011).

50. P. J. Patchett, W. M. White, H. Feldmann, S. Kielinczuk, A. W. Hoffmann, Earth Planet. Sci. Lett. 69, 365 (1984).

51. T. Plank, C. H. Langmuir, Chem. Geol. 145, 325 (1998).

52. F. White, La Végétation de l'Afrique (ORSTOM, IRD/UNESCO, Paris, 1986).

53. C. Assi-Kaudjhis, B. Z. Digbeh, E. Roche, A. M. Lezine, Geo-Eco-Trop. 34, 1 (2010). 
231

232

233

234

235

236

237

238

239

240

241

242

243

244

245

246

247

248

249

250

251

252

253

54. A. Vincens, G. Buchet, M. Servant, ECOFIT Mbalang collaborators, Clim. Past. Discuss. 5, 2577 (2010).

55. I. Reynaud-Farrera, J. Maley, D. Wirrmann, C.R. Acad. Sci. Paris 322, 749 (1996).

56. T. M. Brncic, K. J. Willis, D. J. Harris, W. M. Telfer, R. M. Bailey, The Holocene 19, 79 (2009).

57. T. B. Hart, J. A. Hart, R. Dechamps, M. Fournier, M. Ataholo, in The Biodiversity of African Plants, J. G. Van der Maesen, X. M. Van der Burgt, J. M. Van Medenbach de Rooy, Eds. (Kluwer, Amsterdam, 1996), pp 545-563.

58. A. Ngomanda et al., Clim. Past 5, 647 (2009).

59. J. Preuss, in Paysages de l'Afrique Centrale Atlantique, R. Lanfranchi, D. Schwartz, Eds. (OSTORM, Paris, 1990), pp 260-270.

60. D. M. Taylor, Palaeogeog. Palaeoclimatol. Palaeoecol. 80, 283 (1990).

61. J. Runge, South Afr. Geog. J. 78, 91 (1996).

62. A. Vincens et al., C.R. Acad. Sci., Paris 318,1521 (1994).

63. H. Elenga, D. Schwartz, A. Vincens, Palaeogeog., Palaeoclimatol., Palaeoecol. 109, 345 (1994).

64. H. Elenga et al., C.R. Acad. Sci. Paris 323, 403 (1996).

65. H. Elenga, D. Schwartz, A. Vincens, Bull. Soc. Géol. Fr. 163, 83 (1992).

66. L. M. Dupont, H. Behling, J. H. Kim, Clim. Past 4, 107 (2008).

67. G. Bayon, C. R. German, R. W. Nesbitt, P. Bertrand, R. R. Schneider, Geochem., Geophys., Geosyst. 4, 1025 (2003). 


\section{Acknowledgements}

256 This work was sponsored by the French National Research Agency (ANR), via the ECO-MIST 257 project (\#2010 JCJC 609 01). Core KZAI-01 was collected during the Zaiango project funded by IFREMER and TOTAL (chief scientist: B. Savoye). We warmly thank F. Jansen for providing five radiocarbon dates and giving access to the XRF core-scanner dataset for core GeoB6518. J. Maley is thanked for stimulating discussion, sharing bibliographic resources, and providing Lake Barombi Mbo pollen data. We are very grateful to Y. Germain for help in the laboratory. We also acknowledge W.F. Ruddiman, N.C. Chu, and five anonymous referees for their constructive comments on the manuscript. The data reported in this paper are listed in the Supporting Online Material.

Figure legends

Figure 1: African satellite map with location of the studied core (KZAI-01). A major vegetation change was reported at a number of sites in Central Africa between about 3,000 and 2,000 years ago (yellow stars; see SOM Fig. S1), with evidence for a significant loss of primary forest and expansion of savannas and other pioneer formations. This deforestation event was contemporaneous with the migration of Bantu-speaking agriculturalists originating from the

273 Nigeria-Cameroon area. During the third millennium before present, Bantu farmers spread both 274 southward, across Atlantic Equatorial Africa, and eastward, through the Congo watershed, 275 reaching Angola and the Great Lakes region by around 2,500 yr BP, respectively (thick orange 
arrows). Thin yellow arrows represent subsequent migration waves towards southern Africa.

CAR: Central African Republic; DRC: Democratic Republic of the Congo.

278

Figure 2: $\mathrm{CaO}$ concentrations (wt\%) and $\mathrm{Al} / \mathrm{K}$ ratios versus core depth $(\mathrm{m})$ in core KZAI-01.

The triangles indicate the position of AMS ${ }^{14} \mathrm{C}$ dates for mixed marine carbonate fraction (black) and bulk organic matter (grey), and the age control points tuned to the well-dated nearby core GeoB6518-1 (white). The upper right inset shows the depth versus calendar age plot for KZAI01.

Figure 3: Proxy records for source provenance and chemical weathering intensity in core KZAI01, and comparison with paleoclimatic and paleovegetation records. A) Neodymium and Hafnium isotopic composition in core KZAI-01 (expressed as $\varepsilon_{\mathrm{Nd}}$ and $\varepsilon_{\mathrm{Hf}}$, respectively), as proxies for sediment provenance and chemical weathering intensity.

B) The $\mathrm{Al} / \mathrm{K}$ record from core KZAI-01 indicating variations of chemical weathering intensity in Central Africa. C) Plantwax $\delta \mathrm{D}$ values (\%) in core GeoB6518-1, as an index of precipitation changes in Central Africa

D) The annual Mean Annual Temperature (MAT) record of the Congo Basin in core GeoB

6518-1 based on biomarkers (21). E) Abundance of pollen from herbaceous plants (mainly

293 Graminaea) at the Lake Barombi Mbo (Cameroon), reflecting the relative presence of savannas versus forests in western Equatorial Africa (3). 


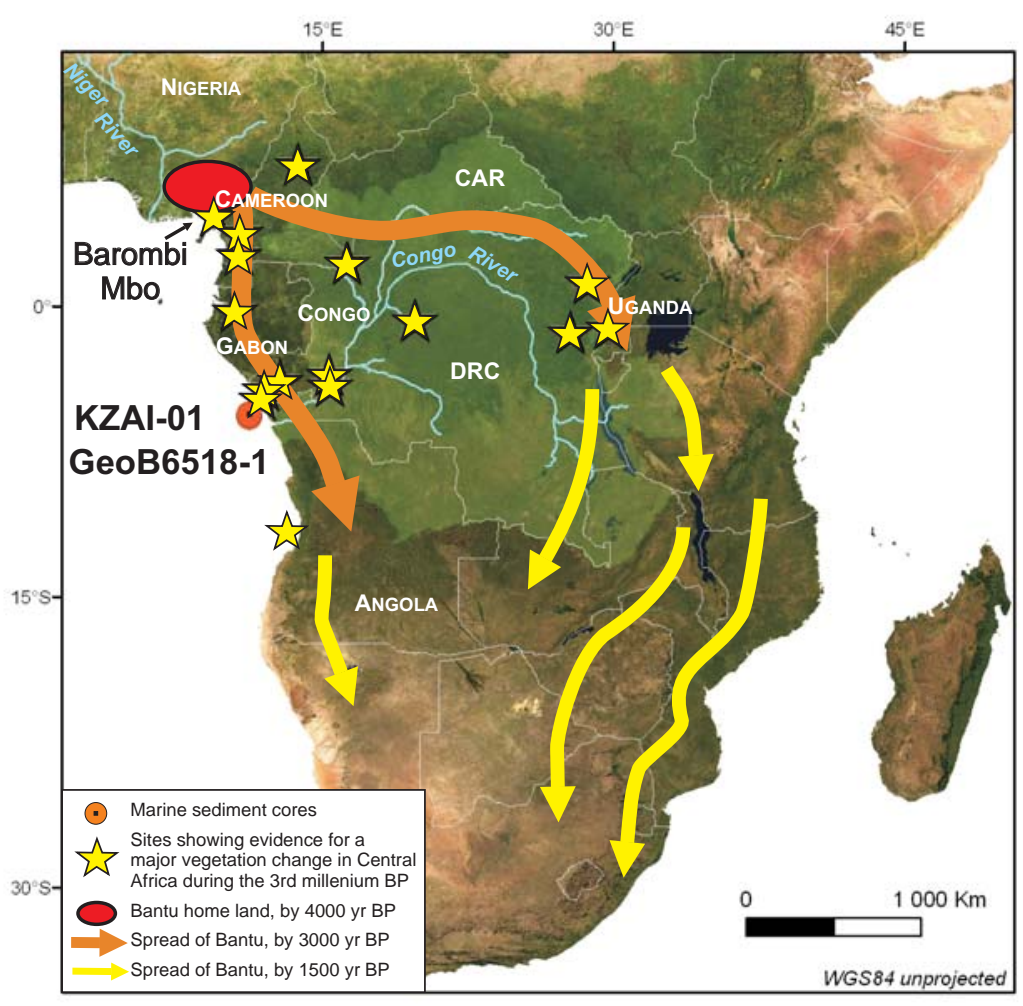

Fig 1 


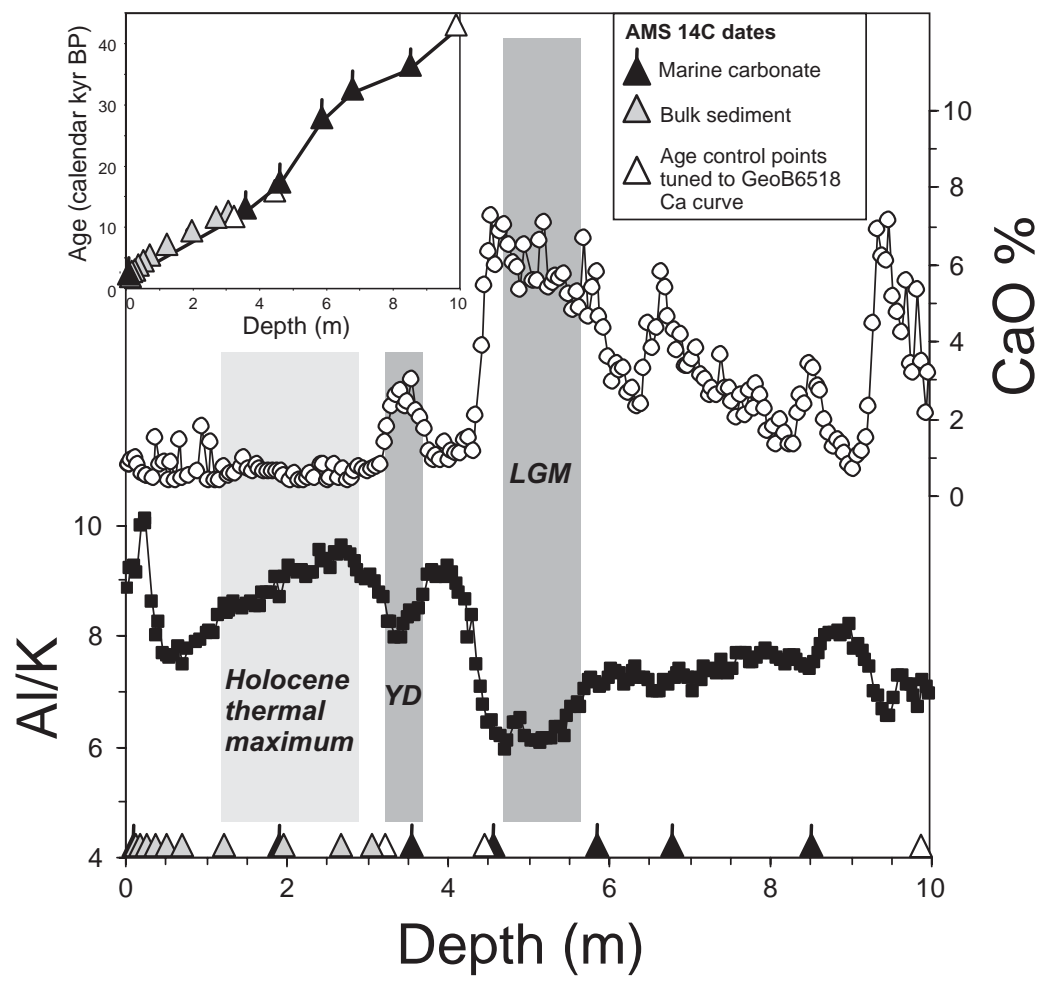

Fig 2 


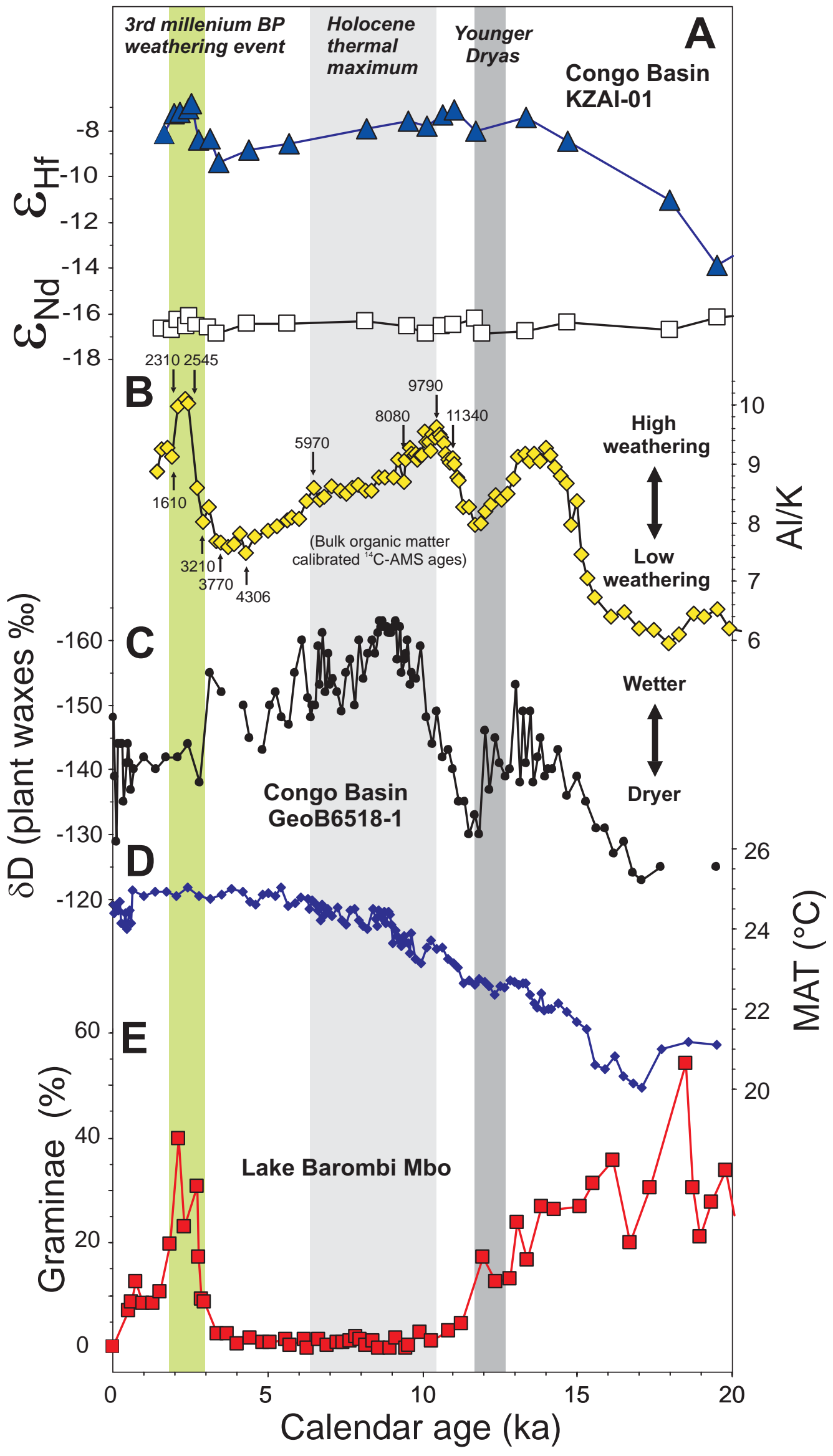

Fig 3 